\title{
KATALOG LUDZKIEJ BEZRADNOŚCI
}

\section{JOHN URRY, WHAT IS THE FUTURE?}

Krzysztof Pietrowicz

Instytut Socjologii, Uniwersytet Mikołaja Kopernika w Toruniu

Ostatnia książka Johna Urry'ego, wydana w 2016 roku, a więc tuż przed jego śmiercią, liczy zaledwie 192 strony. Jest niewielką i nieco szkicowa rozprawa $\mathrm{z}$ bardzo poważnym pytaniem $\mathrm{w}$ tytule: What is the Future? No właśnie: czym jest przyszłość? Autor nie daje jednoznacznej odpowiedzi i skupia się raczej na stworzeniu katalogu tego, czym przyszłość może być. Mamy zatem do czynienia z metanarracją na temat przyszłości, swego rodzaju próbą przeglądu przez wszystkie jutra.

Podstawowa teza książki w największym uproszczeniu brzmi następująco: socjologia (ale może i nauki społeczne w ogóle) powinna zająć się przyszłością. Powinna więc przestać być dyscypliną zorientowaną przede wszystkim na teraźniejszość i przeszłość. Dlaczego? Jak argumentuje autor, przyszłość ,jest zbyt ważna, żeby pozostawić ją w rękach państw, korporacji i inżynierów" (Urry 2016: 7). Można powiedzieć, że rezygnując z zajmowania się tym, co nadejdzie, w tym z badania dyskursów, wyobrażeń i praktyk, w których odbija się zbiorowa troska o jutro, socjologia wyklucza się z uczestnictwa w grze o przyszłość na wielu poziomach.

Myślenie o przyszłości jest czymś powszechnym we wszystkich społecznościach ludzkich. Thomas Suddendorf (2013) twierdzi wręcz, że umiejętność tworzenia scenariuszy dotyczących przyszłości to jedna z dwóch kluczowych cech, które odróżniają ludzi od innych zwierząt: „Myśląc o tym, co może się zdarzyć, wymyślamy potencjalne przyszłe zdarzenia, rozważamy potencjalne możliwości, a następnie umieszczamy je («zagnieżdżamy») w szerszej narracji. To z kolei pozwala nam czynić plany i przygotowywać się do zagrożeń i szans, które dopiero się zmaterializują" (Suddendorf 2018: 
34). Z drugiej strony, czymś innym są nasze naturalne, indywidualne zdolności, a czymś innym próba wyjścia poza wizje przyszłości podejmowane z perspektywy jednostkowej. Jak zatem przejść od intuicji do przedstawień przyszłości, które mają charakter naukowy?

Propozycja Urry'ego może nieco dziwić. Nie przedstawia on bowiem strategii dążącej do standardowo rozumianej „naukowości”, to znaczy opartej na metodologii pozytywistycznej czy postpozytywistycznej. Autor Socjologii mobilności kładzie nacisk na różnorakie „opowieści o przyszłości”, które - jak się wydaje - mają być dla socjologów zarówno środkiem, jak i celem. Jest to widoczne już w pierwszej części książki. Opowiada ona o rozmaitych dyskursach dotyczących przyszłości. Dodajmy: dyskursach wybranych dość przypadkowo, nie widać tu bowiem żadnego schematu porządkującego wybór przedstawionych wizji. W tej części przeczytamy między innymi o druidach, Utopii Tomasza Morusa, filmach Mad Max $2^{1}$ czy Alphaville... A zatem jest to prezentacja odmiennych wizji przyszłości wytwarzanych przez rozmaitych aktorów społecznych, ale - co warto podkreślić - nie naukowców. Przedstawione dyskursy są jedynie przykładami tego, w jaki sposób o przyszłości się mówi.

Również pozostałe części książki Urry’ego nie projektują żadnej nauki o przyszłości, choć postulują obecność socjologii w debacie na temat jutra. Część druga książki wprowadza kontekst systemów złożonych, ale zostają w niej również omówione metody zajmowania się przyszłością czy też tworzenia jej (methods for making future), o których wspominam w dalszej części recenzji. Część trzecia to scenariusze przyszłości, a dokładniej rzecz ujmując trzy studia przypadku. Urry zajmuje się kolejno drukiem 3D (jako technologia mająca potencjał przebudowy społeczeństwa), ewolucją miast oraz zmianami klimatycznymi. Ta część książki wydaje się najmniej dopracowana. Szczególnie widać to we fragmencie dotyczącym druku 3D, gdzie razi naiwność przywoływanych scenariuszy, które dość radykalnie ignoruja rzeczywiste uwarunkowania, zarówno rynkowe, jak i praktyczne. W trzech z czterech scenariuszy, które prezentuje autor, drukarki 3D są przedstawione jako urządzenia bez mała magiczne. Funkcjonują one w świecie idei: nie ma w nim miejsca chociażby na problemy kalibracji czy konserwacji. Nie istnieje też np. problem patentów.

W What is the Future? Urry wzmiankuje kilka ważnych problemów odnośnie do przyszłości, ale nie rozwija ich w sposób satysfakcjonujący. Pierwszy problem, obok którego Urry przechodzi bez głębszej refleksji, do-

${ }^{1}$ Pomylonym zresztą przez autora, gdy idzie o rok wejścia na ekrany kin, z pierwszym filmem z tej serii (Urry 2016: 91). 
tyczy społecznych uwarunkowań rozważań nad przyszłością. Mamy tu do czynienia z dość oczywistym punktem wyjścia: w przyszłość wchodzimy tyłem (por. Zybertowicz 2003). To znaczy, że możemy rejestrować i badać empirycznie jedynie to, co miało już miejsce; a zatem to przeszłość warunkuje nasze poznanie. Nie jest to w żadnym razie idea nowa i w swej najprostszej postaci jest zwykłą oczywistością. Walter Benjamin w słynnym eseju O pojeciu historii pokazuje jednak jej wielowymiarowość, interpretując obraz Paula Klee Angelus Novus. Obraz ten

[p]rzedstawia anioła, który wygląda, jak gdyby chciał się oddalić od czegoś, w co się wpatruje. Oczy szeroko rozwarte, usta otwarte, skrzydła rozpięte. Tak musi wyglądać anioł historii. Zwrócił oblicze ku przeszłości. Gdzie nam ukazuje się łańcuch zdarzeń, on widzi jedną wieczną katastrofę, która nieustannie piętrzy ruiny na ruinach i ciska mu pod stopy. Chciałby zatrzymać się, zbudzić umarłych i złączyć to, co rozbite. Ale od raju wieje wicher, który napiera na skrzydła i jest tak silny, że anioł nie może ich złożyć. Ten wicher pędzi go niepowstrzymanie w przyszłość, do której jest zwrócony plecami, podczas gdy przed nim rośnie stos ruin. Tym wichrem jest to, co nazywamy postępem (Benjamin 1996: 41).

Ta historiozoficzna metafora pokazuje złożoność relacji między przeszłością, teraźniejszością i przyszłością, której nie widać w książce Urry'ego.

Brytyjski socjolog dostrzega, rzecz jasna, problem uwarunkowania opisów przyszłości. Zdaje sobie też sprawę z tego, że pisze w momencie triumfu idei katastroficznych, wśród których na pierwszy plan wysuwa się problem zmian klimatycznych. Olbrzymie wrażenie robi zresztą umieszczony w pierwszej części pracy spis kilkudziesięciu monografii naukowych i popularnonaukowych zawierających właśnie katastroficzne wizje przyszłości (Urry 2016: 36-37). Urry traktuje jednak apokaliptyczny nastrój jako oczywistość. Oznacza to marginalizację ważnej niegdyś dla nauk społecznych idei postępu, która jedynie jest wzmiankowana. Wśród wizji przyszłości opisywanych w pierwszej części nie ma na przykład nauk społecznych w służbie ideologii postępu. Nie ma też, przechodząc już do współczesności, Francisa Fukuyamy głoszącego koniec historii (1996) czy też krytykowanych przez Evgeny'ego Morozova solucjonistów (Morozov 2013), widzących w technologii narzędzie rozwiązania wszelkich problemów społecznych. Z perspektywy roku 2018 brakuje wzmianek o transhu- 
manizmie (np. Harari 2018) i ponownym odrodzeniu idei postępu (np. Pinker 2018). Dodać trzeba, że te ostatnie tendencje pojawiły się relatywnie niedawno i w momencie pisania książki mogły być dla Urry’ego jeszcze niedostrzegalne.

W tym miejscu warto wspomnieć o jeszcze jednym problemie. Mianowicie: czy przyszłość zawsze jest czymś przyszłym? Pytanie to brzmi nieco paradoksalnie, ale wskazuje na pewne niewielkie pęknięcie w narracji książki, nad którym autor przechodzi do porządku dziennego. Urry w pewnym momencie cytuje znanego pisarza science fiction, Williama Gibsona, który wypowiedział często powtarzaną frazę „Przyszłość już tu jest - tylko niezbyt równo rozłożona" (Urry 2016: 17). Jeśli przyjmujemy takie założenie, to badanie przyszłości jest tak naprawdę badaniem pewnych fragmentów teraźniejszości. A zatem jest to przejście w stronę dość standardowej socjologii, w której analizujemy celowo dobrane studia przypadków, będące swoistymi „wyspami przyszłości” w tym sensie, że społeczeństwa wkrótce podążą droga ich rozwoju. Kluczowa z tej perspektywy staje się selekcja tych przypadków, i tu Urry nam nie pomaga.

To prowadzi nas do kolejnego problemu, który nie jest wyartykułowany, ale uważny czytelnik dostrzeże go w trakcie lektury. Dotyczy on metodologii i narzędzi służących badaniu przyszłości. Metody, które Urry omawia w rozdziale szóstym, są de facto zawężone do analizy i produkcji pewnych narracji o przyszłości. Kolejno są tam wymienione: wyciąanie wniosków z dawnych wizji przyszłości, analiza „upadłych” przyszłości (tj. nietrafnych przewidywań dokonywanych w momentach istotnych zmian), badanie dystopii oraz utopii, ekstrapolacja trendów oraz tworzenie scenariuszy przyszłości. Ta ostatnia metoda jest dla autora najważniejsza. Lektura tego rozdziału nasuwa pytanie o miejsce na próby zmatematyzowanej nauki o przyszłości. Jak do propozycji Urry’ego ma się choćby obietnica badaczy z kręgu big data, którzy wieszczą możliwość przewidywania zachowań jednostek i całych społeczeństw? Z perspektywy autora badania ilościowe nad przyszłościa po prostu nie istnieją.

I wreszcie: problem, który Urry owszem dostrzega, ale umieszcza zdecydowanie na marginesie głównej narracji, mimo że jest to zagadnienie o kluczowym znaczeniu dla socjologii (Urry 2016: 79). Chodzi o możliwość kreowania przyszłości. Z jednej strony jest to jeden z istotnych kontekstów instytucjonalizacji nauk społecznych. Robert Merton piszący o samospełniających i samoobalających się proroctwach czy dużo wcześniej Karol Marks formułujący słynną jedenastą tezę o Feuerbachu: „Filozofowie rozmaicie tylko interpretowali świat; idzie jednak o to, aby go zmie- 
nić" (Marks 1975: 8) - to pewnie najbardziej znane przykłady artykulacji różnych możliwości naukowego tworzenia przyszłości. Paradoksalnie dość podobna jest perspektywa technokratyczna czy też solucjonistyczna (Morozov 2013). Przypomnę często przytaczane zdanie Alana Kaya z Xerox PARC, który na początku lat 70. XX wieku powiedział: „Najlepszy sposób, by przewidzieć przyszłość, to po prostu ją wynaleźć. Naprawdę bystrzy ludzie, jeżeli zapewnić im odpowiednie finansowanie, są w stanie zrobić dosłownie cokolwiek, o ile nie gwałci to zbyt wielu praw Newtona!' (cyt. za: Gillies, Cailliau 2000: 187). Oto perspektywa inżynieryjna w czystej postaci. Przyszłość jako coś, co należy skonstruować, a może raczej jako coś, co jest konstruowane przez innowatorów działających na rynku. I znów pytanie, jaka powinna być w tym kontekście rola socjologii?

Gdybym miał swoją recenzję zawrzeć w jednym zdaniu, napisałbym, że What is the Future? kataloguje nie wizje jutra, ale rodzaje ludzkiej bezradności względem tego, co nadejdzie. Dla Urry’ego przyszłość, która możemy się zajmować, to bowiem przede wszystkim nasze wyobrażenia o niej, a zatem po prostu pewien rodzaj dyskursu. Nie jest to przyszłość w znaczeniu tego, co nastąi, ale wyraz naszych obecnych pragnień i obaw. Nawiązując do cytowanego wcześniej Suddendorfa, możemy powiedzieć, że dopóki tworzymy scenariusze przyszłości (i umieszczamy je w szerszej narracji), dopóty pozostajemy ludźmi. Książka Urry’ego tymczasem pozostawia czytelnika z wrażeniem, że nawet wyposażeni w owe scenariusze, jesteśmy wobec przyszłości bezradni.

Po lekturze pracy Urry'ego wiemy, że jako badacze społeczni powinniśmy się przyszłością zajmować. Ta teza jest uzasadniona i nie budzi kontrowersji. Natomiast nie uzyskujemy odpowiedzi na pytanie, którą ścieżką socjologia powinna podążać. Czy powinniśmy tworzyć jakościowe scenariusze przyszłości (co przede wszystkim sugeruje Urry), czy raczej próbować przyszłość matematyzować i wykorzystywać big data dla uzyskania wiedzy o przyszłych stanach rzeczywistości społecznej? Czy należy przyszłość jedynie opisywać, czy może trzeba przyjąć strategię inżynieryjną (lub interwencyjna) i przyszłość kreować? Dylematy te odzwierciedlają w pewnym sensie centralne problemy metodologii nauk społecznych: badania jakościowe czy ilościowe? Neutralność czy zaangażowanie? Pytając z Urrym o to, czym jest przyszłość, natrafimy więc na stare problemy. Nie znajdziemy ani prognoz, ani wskazówek co do tego, jak socjologicznie przewidywać to, co się zdarzy. Od czegoś jednak trzeba zaczać - dla kogoś, kto chciałby zajmować się problematyka przyszłości, książka What is the Future? jest całkiem dobrym punktem wyjścia. 
Bibliografia:

/// Benjamin W. 1996. O pojeciu historii, tłum. K. Krzemieniowa, [w:] tegoż, Aniot historii. Eseje, sækicice, fragmenty, wybór i opracowanie H. Orłowski, Wydawnictwo Poznańskie, s. 413-424.

/// Fukuyama F. 1996. Koniec historii, tłum. T. Bieroń, Wydawnictwo Zysk i S-ka.

/// Gillies J., Cailliau R. 2010. How the Web Was Born. The Story of the World Wide Web, Oxford University Press.

/// Harari Y.N. 2018. Homo deus: krótka historia jutra, tłum. M. Romanek, Wydawnictwo Literackie.

/// Marks K. 1975. Tezy o Feuerbachu, [w:] K. Marks, F. Engels, Dzieła, t. 3, Książka i Wiedza, s. 5-8.

/// Morozov E. 2013. To Save Everything, Click Here: The Folly of Technological Solutionism, Public Affairs.

/// Pinker S. 2018. Enlightenment Now. The Case for Reason, Science, Humanism and Progress, Viking.

/// Suddendorf T. 2013. The Gap. The Science of What Separates Us from Other Animals, Basic Books.

/// Suddendorf T. 2018. Wewnatrz naszej glowy, „Świat Nauki”, nr 10(326), s. 31-35.

/// Urry J. 2016. What is the Future, Polity Press.

/// Zybertowicz A. 2003. „W przyszłość wkeraczamy tytem”. Uwagi o cywilizacji współczesnej, [w:] Konstruktywizm w bumanistyce, red. A. Pałubicka, A.P. Kowalski, Oficyna Wydawnicza Epigram, s. 99-102.

/// Krzysztof Pietrowicz - socjolog, adiunkt w Instytucie Socjologii Uniwersytetu Mikołaja Kopernika w Toruniu. Zainteresowany między innymi tym, w jaki sposób technologie zmieniają zbiorowości ludzkie. Autor monografii: Maszyny społeczne (2013; wspólnie z Lukaszem Afeltowiczem) oraz Podejscia sieciowe w socjologii (2016).

Email: krzysztof.pietrowicz@umk.pl 